\title{
Analysis of Solid Waste Generation in a Wood Processing Machine
}

\author{
Diego Henrique de Almeida ${ }^{1, *}$, Tiago Hendrigo de Almeida ${ }^{2}$, Fabiane Salles Ferro² ${ }^{2}$ Eduardo Chahud ${ }^{3}$, \\ Luiz Antonio Melgaço Nunes Branco ${ }^{4}$, André Luís Christoforo ${ }^{1}$, Francisco Antonio Rocco Lahr ${ }^{5}$
}

\author{
${ }^{1}$ Department of Civil Engineering (DECIv), Federal University of São Carlos (UFSCar), São Carlos, Brazil \\ ${ }^{2}$ Department of Materials Engineering (SMM), Engineering School of São Carlos (EESC), São Paulo University (USP), São Carlos, Brazil \\ ${ }^{3}$ Department of Civil Engineering, Federal University of Minas Gerais (UFMG), Belo Horizonte, Brazil \\ ${ }^{4}$ Faculty of Engineering and Architecture, FUMEC University, Belo Horizonte, Brazil \\ ${ }^{5}$ Department of Structures Engineering (SET), Engineering School of São Carlos (EESC), São Paulo University (USP), São Carlos, Brazil
}

\begin{abstract}
The processing of the wood generates a significant amount of waste, presenting itself as a problem to the environment. The volume of waste generated from processing depends, in addition to other factors, on the type of processing machine. This work aimed to present a case study regarding the volume of waste generated in the processing of the logs of Eucalyptus sp.genus specie using processing machine Pica-Pau type. Pica-Pau type machine was located in Itapeva (state of São Paulo, Brazil). A total of 38 logs were used, with na average diameter of $34 \mathrm{~cm}$ (excluding the bark and measured at base and top of the $\log$ ), average length of $3 \mathrm{~m}$ and conicity of $1 \%$. The average volume of $38 \operatorname{logs}$ was equal to $10.35 \mathrm{~m}^{3}$ and the volume of residues generated during log processing was $2.17 \mathrm{~m}^{3}$, implying a transformation coefficient $\left(C_{t}\right)$ of $79 \%$. Processing machine Pica-Pau type was classifies a good machine to be used in the processing of logs, however, the processing time is higher than the time used by the most used band saws, making it less attractive in the processing of wood by large companies. From the qualitative point, the waste generated in the production of the plank is mostly the sawdust.
\end{abstract}

Keywords Eucalyptus sp., Log, Sawdust, Waste, Wood

\section{Introduction}

Wood can be used of several ways, for examples, in civil construction as structural members or materials to buildings and as raw material to panels and furniture industries [1-4]. In Brazil, woods of the genus Pinus and Eucalyptus from planted forests are used by this companies [5, 6].

One of the most important phases of the transformation of the wood into the most diversified products is its first processing, which must be carried out in a rational way taking full advantage of the $\log$ with the least possible residue production [7].

However, timber industries, particularly sawmills, generate a large amount of residue, with low yields of timber production, since the necessary uses of these wastes are not always given, which are dispersed and can lead to serious environmental and social problems [8].

It is estimated that the loss of wood in the first processing is around $50 \%$ of the original volume of the wood log used,

* Corresponding author:

diegoestruturas@gmail.com (Diego Henrique de Almeida)

Published online at http://journal.sapub.org/ijaf

Copyright @ 2017 Scientific \& Academic Publishing. All Rights Reserved that is, not only the problems of pollution, but also the economic problem with the waste of the raw material [9-13].

The company was chosen to carry out this research because it presents a different method of first processing than is usually used in the other sawmills of the region, using an alternative saw, wood processing machine, called Pica-Pau type. Company still uses this machine because, according to its directors, its main focus is the treatment of roundwood, that is, whole wood, and sometimes some customers order for sawed pieces of the genus Eucalyptus sp.

The aim of this paper was investigate the solid waste generation (qualitatively and quantitatively) during first processing of $\log$ in an alternative saw, wood processing machine, Pica-Pau type.

\section{Material and Methods}

The wood processing machine Pica-Pau type (Fig. 1.a) studied in this research was installed in a company located in the Itapeva city, state of São Paulo, Brazil. For study of waste volume were considered 38 logs of Eucalyptus sp. wood genus (Fig. 1.b) with average diameter (disregarding of bark and measured at the base and top of the $\log$ ), length and conicity equal to $34 \mathrm{~cm}, 3 \mathrm{~m}$ and $1 \%$, respectevely, with the 
average extraction of 10 planks per log.

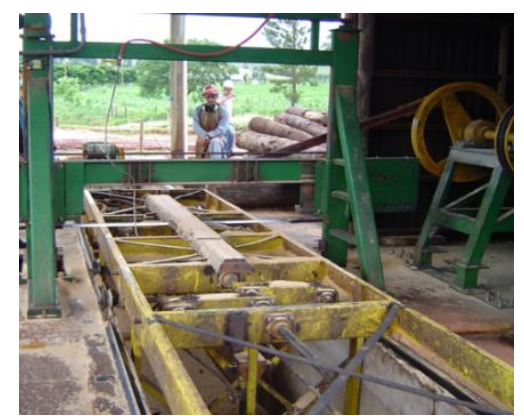

(a)

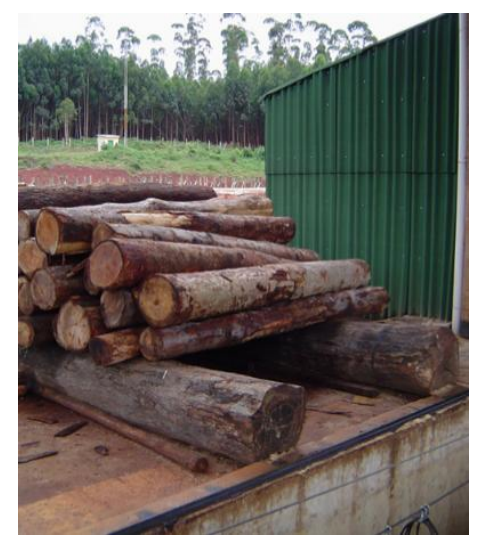

(b)

Figure 1. (a) Wood processing machine Pica-Pau type; (b) Eucalyptus sp. wood genus logs

After all necessary adjustments (Fig 2.a), the machine is driven causing the track to move horizontally toward the saw blade that moves perpendicularly to the movement of the log for removal of the planks (Fig. 2.b). Planks generated from wood processing had an average thickness of $2.50 \mathrm{~cm}$, a length of $3 \mathrm{~m}$ and well varied widths (Fig. 2.b).

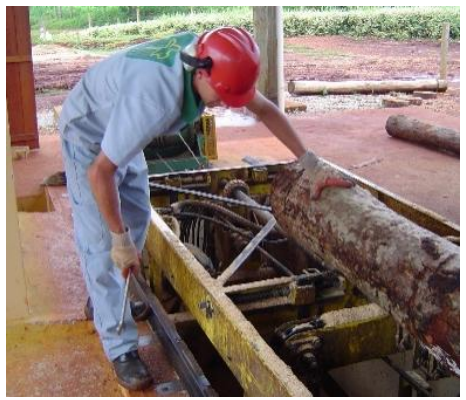

(a)

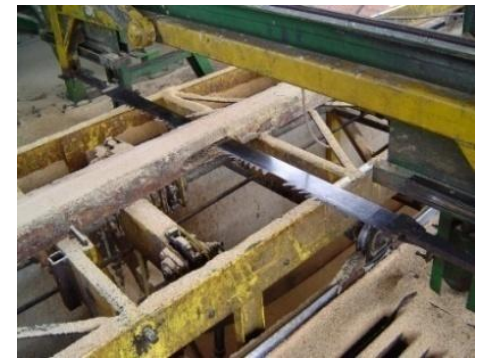

(b)

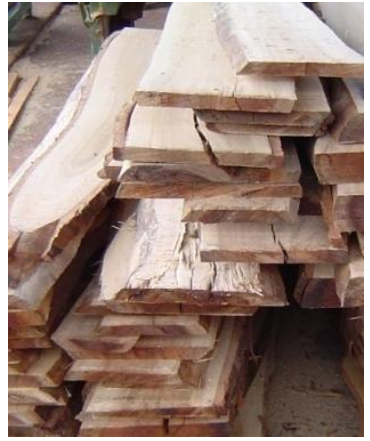

(c)

Figure 2. (a) Machine adjustments; (b) First processing of Eucalyptus sp. $\log$; (c) Produced planks by machine Pica-Pau type

Eq. 1 present the count of the volumes of logs with cone trunk geometry (Fig. 3), where $L$ denotes the length of the $\operatorname{logs}, n_{t}$ is the total number of logs processed and $D_{t}$ and $D_{b}$ are the diameters measured at the base and at the top of the roundwood, respectively. The total volume $\left(V_{t o r}\right)$ corresponding to the $38 \operatorname{logs}$ calculated by Equation 1 was equal to $10.35 \mathrm{~m}^{3}$.

$$
V_{t o r}=\frac{\pi}{12} \cdot \sum_{i=1}^{n_{t}} L_{i} \cdot\left(D t_{i}^{2}+D b_{i}^{2}+D t_{i} \cdot D b_{i}\right)
$$

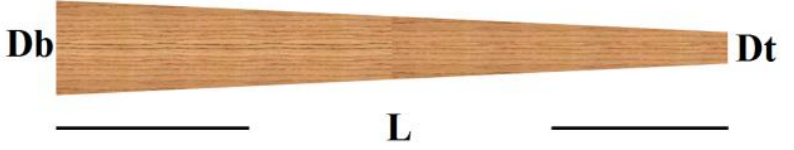

Figure 3. Geometry considered to total volume of logs

After selecting the 38 logs and calculating their respective volumes, the estimated volume of residues $\left(V_{\text {res }}\right)$ was obtained by the difference between the volume of the logs and the total volume of the planks $\left(V_{t a}\right)$ (Eq. 3), where the total volume of the boards was obtained by means of Eq. 2, considering the geometry of each plank (Fig. 4).

$$
\begin{gathered}
V_{t a}=\frac{1}{2} \cdot \sum_{i=1}^{n_{t a}} L_{i} \cdot\left(e_{1 i} \cdot t_{1 i}+e_{2 i} \cdot t_{2 i}\right) \\
\text { Vres }=\text { Vtor }- \text { Vta }
\end{gathered}
$$

From Eq. 2, $e_{1}$ and $e_{2}$ are thickness measureds at extremities of planks, $t_{1}$ and $t_{2}$ are width measureds at extremities of planks and $n_{t a}$ is the total number of planks.

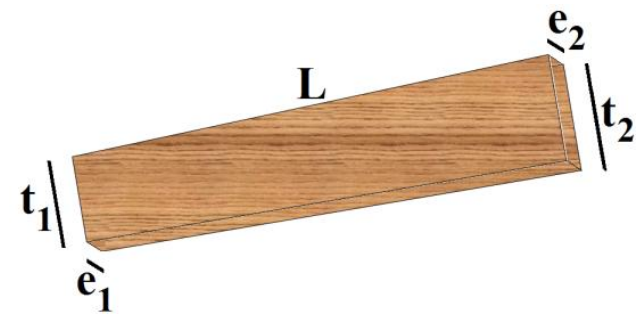

Figure 4. Geometry considered to volume of planks

The efficiency of the wood processing machine Pica-Pau type $\left(C_{t}\right)$ was calculated by Eq. 4, expressed as a percentage. 


$$
C_{t}=\frac{V_{t a}}{V_{t o r}} \cdot 100(\%)
$$

\section{Results and Discussions}

Using Eq. 3, the volume of residues generated during processing of the 38 Eucalyptus wood genus logs was 2.17 $\mathrm{m}^{3}$. This volume of waste is equivalent to $20.97 \%$ of the total volume of the logs, implying a transformation coefficient of $79 \%$, which classifies the Pica-Pau type as a good machine to be used in the processing of logs.

However, a negative point for its use is the processing time, which is higher than the time used by other machines used by the industry [9-18], which makes it impossible to use it in the processing of roundwood by large companies, due to increased competitiveness and technological advances aimed at minimizing waste production with the shortest time of machine operations [16].

It can be observed that, even with this machine that has a high conversion value $\left(C_{t}=79 \%\right)$, there is a considerable waste production, being the use of techniques that minimize the formation of residues a systemic practice during the processes of logs in sawmills, always aiming at improving production lines to reduce waste generations.

Qualitative analysis of resídue

From the qualitative analysis, the residues generated in the processing machine Pica-Pau type are mostly saw dust. The sawdust was deposited in a special compartment for collecting the residue (Fig. 5) or on the different points of machine elements (Fig. 6).

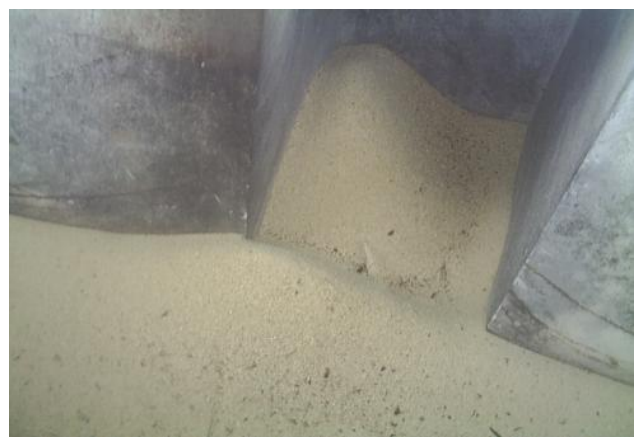

Figure 5. Sawdust generated by process with Pica-Pau type machine on the compartment for collecting

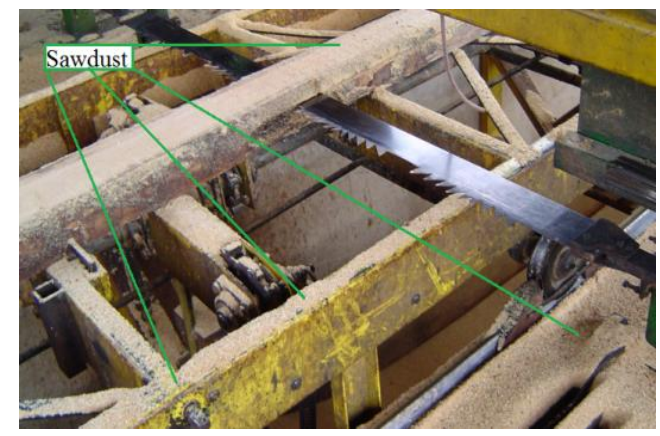

Figure 6. Sawdust generated on the different points of machine elements

\section{Conclusions}

Researches on waste production in the wood process industries is important for improvements in this sector. This study of, processing machine Pica-Pau type, proved to be eficient in agreement with the low production of waste versus the quantity of planks produced, however, the required processing time is higher than the time used by other machines with the same purpose, making it less attractive in large sawmills.

\section{REFERENCES}

[1] Almeida, T. H.; Almeida, D. H.; Araujo, V. A.; Silva, S. A. M.; Christoforo, A. L.; Lahr, F. A. R. Density as estimator of dimensional stability quantities of Brazilian tropical woods. BioResources. v. 12. n.3, p. 6579-6590, 2017.

[2] Almeida, T. H.; Almeida, D. H.; Ferro, F. S.; Varanda, L. D.; Campos, C. I.; Christoforo, A. L.; Lahr, F. A. R. Avaliação da qualidade na produção industrial de compensados por meio de teses de flexão e de cisalhamento. Madeira: Arquitetura e Engenharia. v.12, p. 45-50, 2011.

[3] Almeida, D. H.; Ferro, F. S.; Varanda, L. D.; Souza, A. M.; Icimoto, F. H.; Christoforo, A. L.; Lahr, F. A. R. Quality control in plywood manufacturing: physical properties of commercial plywood of Pinus sp. International Journal of Composite Materials. v. 3, p. 163-167, 2013.

[4] Almeida, T. H. Criação e implantação de procedimentos logísticos em uma indústria de móveis: estudo de caso.51 p., 2013. Monografia (Graduação em Engenharia Industrial Madeireira). Campus Experimental de Itapeva, Universidade Estadual Paulista, Itapeva, 2013.

[5] Almeida, D. H. Análise das resistências ao embutimento e de compressão para madeiras de Pinus e Eucalipto. 100 p., 2011. Monografia (Graduação em Engenharia Industrial Madeireira). Campus Experimental de Itapeva, Universidade Estadual Paulista, Itapeva, 2011.

[6] Almeida, D. H.; Almeida, T. H.; Molina, J. C.; Ferro, F. S.; Christoforo, A. L.; Lahr, F. A. R. Embedment strength of Pinus sp. wood to metal pins. Advanced Materials Research. v.884, p. 653-656, 2014.

[7] Gonçalves, M. T. T. Processamento da madeira. Bauru: Center Xerox, 2000. 242p.

[8] Brand, M. A.; Muñiz, G. I. B.; Silva, D. A.; Klock, U. Caracterização do rendimento e quantificação dos resíduos gerados em serraria através do balanço de materiais. Revista Floresta. v. 32, n.2, p 247-259, 2002.

[9] Murara Junior, M. I.; Rocha, M. P.; Timofeiczyk Junior, R. Rendimento em madeira serrada de Pinus taeda para duas metodologias de desdobro. Revista Floresta. v. 35, n.3, p 473-483, 2005.

[10] Vieira, R. S.; Lima, J. T.; Silva, J. R. M.; Hein, P. R. G.; Baillères, H.; Baraúna, E. E. P. Small wooden objects using Eucalypts sawmill wood waste. BioResources. v. 5, n.3, p 1463-1472, 2010. 
[11] Ofoegbu, C.; Ogbonnaya, S.; Babalola, F. D. Sawmill conversion efficiency and wood recovery of timber species in Cross River State Nigeria. Agriculture and Forestry. v.60, n.1, p. 105-113, 2014.

[12] Silva, C. P.; Vieira, R. S.; Silva, I. C.; Pereira, A. S.; Baraúna, E. E. P. Quantification of waste produced in the Gurupi, TO lumber industry. Floresta e Ambiente. v.24, e00065613, 2017.

[13] Monteiro, T. C.; Lima, J. T.; Silva, J. R. M.; Trugilho, P. F.; Baraúna, E. E. P. Energy balance in sawing Eucalyptus grandis logs. BioResources. v.12, n.3, p. 5790-5800, 2017.

[14] Almeida, D. H.; Poleto, S. F. S.; Almeida, T. H.; Lahr, F. A. R. Análise da geração de resíduos sólidos no processamento da madeira em máquina tipo Pica-Pau. In: III Simpósio sobre Resíduos Sólidos (SIRS), 2013, São Carlos.

[15] Fagundes, H. A. V. Produção de madeira serrada e geração de resíduos do processamento de madeira de florestas plantadas no Rio Grande do Sul.173 p., 2003. Dissertação (Mestrado em Administração). Universidade Federal do Rio Grande do Sul, Porto Alegre, 2010.

[16] Heinrich, D. Simulação da produção de madeira serrada.158 p., 2010. Dissertação (Mestrado em Inovação na Edificação). Universidade Federal do Rio Grande do Sul, Porto Alegre, 2003.

[17] Dutra, R. I. J. P.; Nascimento, S. M.; Numazawa, S. Resíduos de indústria madeireira: caracterização, consequências sobre o meio ambiente e opções de uso. Revista Científica Eletrônica de Engenharia Florestal.n.5, p 1-19, 2005.

[18] Alves, L. S.; Silva, S. A. M.; Azambuja, M. A.; Varanda, L. D.; Christoforo, A. L.; Lahr, F. A. R. Particleboard produced with sawmill waste of different wood species. Advanced Materials Research. v. 884, p. 689-693, 2014. 